\title{
Cigarettes and Other Tobacco Products Act (COTPA) implementation in education institutions in India: A cross- sectional study
}

\author{
Akash Pradhan', Kunal Oswal', Asim Padhan', Sanjay Seth², Ashima Sarin², Lakshman Sethuraman', Paul Sebastian', \\ Arnie Purushotham ${ }^{1,3}$
}

\begin{abstract}
INTRODUCTION Tobacco use is a major risk factor for cancer and other noncommunicable diseases and is the single largest cause of preventable deaths worldwide causing premature death. There are various laws and legislations for tobacco control in India. The Cigarettes and Other Tobacco Products Act (COTPA) 2003 was enacted in 2004 but is not enforced rigorously. The aim of this study was to determine any violation of COTPA Section 4 (prohibition of smoking in public places) around educational institutions and Section $6 \mathrm{~b}$ (prohibition of sale of tobacco products near educational institutions).

METHODS A cross-sectional, observational study was conducted in 307 schools and colleges selected across 12 districts in 5 states in India. Data were collected by the tobacco control coordinators. From the centre of the city, the coordinators travelled in four different directions to a maximum distance of $10 \mathrm{~km}$ radius. Along the path, any educational institutions that were encountered were surveyed for violation of COTPA Sections 4 and $6 \mathrm{~b}$.

RESULTS Out of 307 schools surveyed across the five states, an average of $85 \%$ of the schools violated Section 4 and an average of $69 \%$ violated Section $6 \mathrm{~b}$.

CONCLUSIONS A coordinated effort by all stakeholders, especially by the police, educational institutions, and the community, is required. Adherence to the guidelines on Tobacco-Free Educational Institutions can improve the implementation of COTPA in and around educational institutions.
\end{abstract}

\section{AFFILIATION \\ 1 Tata Trusts Cancer Care Program, Mumbai, India \\ 2 Sambandh Health Foundation, \\ Haryana, India \\ 3 School of Cancer and \\ Pharmaceutical Sciences, King's College London, London, United Kingdom}

\section{CORRESPONDENCE TO}

Akash Pradhan. Tata Trusts Cancer Care Program, Bombay House, 24 Homi Mody Street, Mumbai, 400 001, India. E-mail: pradhanakash108@ gmail.com ORCID ID: https://orcid. org/0000-0002-8797-8233

\section{KEYWORDS}

tobacco smoking, tobacco control, educational institutions, monitoring and compliance, laws and policies, short report

Received: 8 May 2020

Revised: 22 July 2020

Accepted: 24 July 2020

\section{INTRODUCTION}

Tobacco use is a major risk factor for cancer and other non-communicable diseases and is the single largest cause of preventable deaths worldwide causing premature death in half of its users ${ }^{1,2}$. According to the Global Adult Tobacco Survey 2017, 28.6\% of adults aged $\geq 15$ years (approximately 266.8 million people) use some form of tobacco in India ${ }^{3}$.

There are various laws and legislations for tobacco control in India ${ }^{4}$. The Government of India enacted in 2004 its comprehensive tobacco control law the Cigarettes and other Tobacco Products Act 2003 (COTPA 2003) (prohibition of advertisement and regulation of trade and commerce, production, supply and distribution), to reduce tobacco use $\mathrm{e}^{5}$. This Act includes: a) Section 4, prohibition of smoking in public places; b) Section 5, prohibition of advertisement of cigarettes and other tobacco products; c) Section 6, prohibition of sale of cigarettes or other tobacco products to anyone below the age of 18 years and in a particular area; and d) Section 7, prohibition on trade and commerce in production, supply, and distribution of cigarettes and other tobacco products.

While promulgation of a law is usually a onetime process, its implementation is a continuous 
and more difficult process to enforce. According to the Global Youth Tobacco Survey (GYTS), 2009, $14.6 \%$ of students in India, aged $13-15$ years, use tobacco ${ }^{7}$. Breslau et al. ${ }^{8}$ reported that persons who smoked their first cigarette at 14-16 years of age were 1.6 times more likely to become dependent than those who initiated smoking at an older age. Therefore, to achieve tobacco control amongst youth, it is essential that there should be strict enforcement of the COTPA Act in the vicinity of educational institutions. The Government of India released the 'Guidelines for Tobacco-Free Schools/Educational Institutions' in 2019 and 'Step-by-Step Guidelines for implementation of Section $6 \mathrm{~b}$ of the Act and Rules' in $2017^{9,10}$.

Since the premises of all educational institutions, by their nature, are public places, smoking inside the premises of an educational institution is a violation of Section 4 of the COTPA. For Section 6b, no tobacco products must be sold in an area within 100 yards (about $91 \mathrm{~m}$ ) of the premises. The primary objective of this study was to determine any violation of COTPA Section 4 (prohibition of smoking in public places) around educational institutions and Section $6 \mathrm{~b}$ (prohibition of sale of tobacco products near educational institutions). The secondary objective was to report the findings to the District Education Officer and Superintendent of Police in order to sensitize them on the need for better enforcement of COTPA laws related to educational institutions.

\section{METHODS}

Between November and December 2019, a crosssectional, observational study was conducted in 307 schools and colleges selected across 12 districts in 5 states (Jharkhand, Karnataka, Andhra Pradesh, Uttar Pradesh, Odisha) in India. The educational institutions were selected using random sampling. The schools were anonymized. Schools within a $10 \mathrm{~km}$ radius from the center of the city were selected. The data were collected by the tobacco control coordinators of the Tata Trusts Cancer Care Programme.

The outcome measures were rates of violation of Sections 4 and $6 \mathrm{~b}$ of COPTA:

1. Display of 'No Smoking Area - Smoking here is An Offence' signage in the entrance(s) of educational institutions, as per Section 4 of COTPA. Such signage must be of $90 \times 60 \mathrm{~cm}$ dimensions. A typical signage is shown in Figure 1.

2. Shops selling tobacco products within a radius of 100 yards of the educational institutions, as per Section $6 \mathrm{~b}$ of COTPA.

To measure the violation of Section $6 \mathrm{~b}$, the data collectors measured a radial distance of approximately 120 yards from the educational institution's entrances/exits, wherever possible, using Google Maps, and checked if there were any shops selling tobacco products within this radius. The observations were recorded photographically. The geographical locations of the educational institutions are shown in Figures 2 and 3.

A descriptive analysis was performed to report the data. No personnel of the educational institutions or any authority outside the institutions were interviewed or informed about the survey.

\section{RESULTS}

Out of 307 schools observed, on average $85 \%$ of the schools violated Section 4 - no signage displaying 'No Smoking Area - Smoking here is An Offence', and on average $69 \%$ violated Section $6 \mathrm{~b}$ - shops selling tobacco products within a radius of 100 yards of schools (Supplementary file, Table 1).

\section{Violation of Section 4 of COTPA}

It was observed (Figure 4) that in Anantapur and Chittoor districts of Andhra Pradesh, 100\% of the educational institutions violated Section 4. In Prayagraj district of Uttar Pradesh an average of 96\%, in Khordha, Cuttack and Puri districts of Odisha an average of 91\%, in Gumla, Khunti, Lohardaga and

\section{Figure 1. No-smoking signage for educational} institutions as per COTPA Section 4

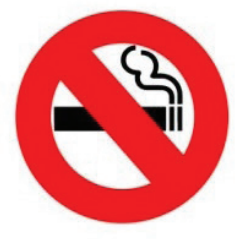

\section{No Smoking Area Smoking here is an offence}

\section{The violators can be challaned with fine of Rs. 200/-}

In case someone smokes here, please report to following Authority

Name:

Designation: 
Figure 2. Geo-tags of the educational institutions

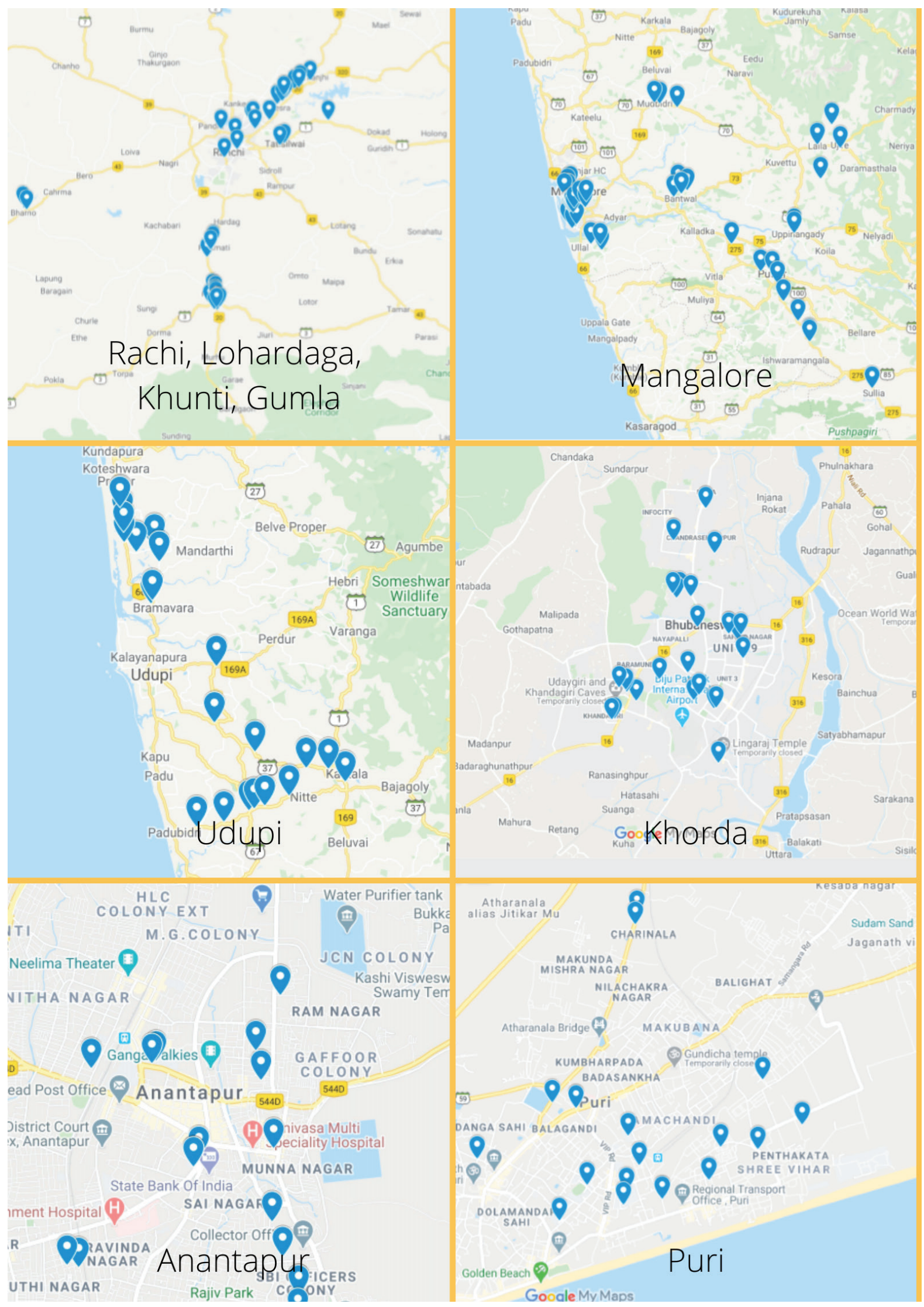


Figure 3. Geo-tags of the educational institutions

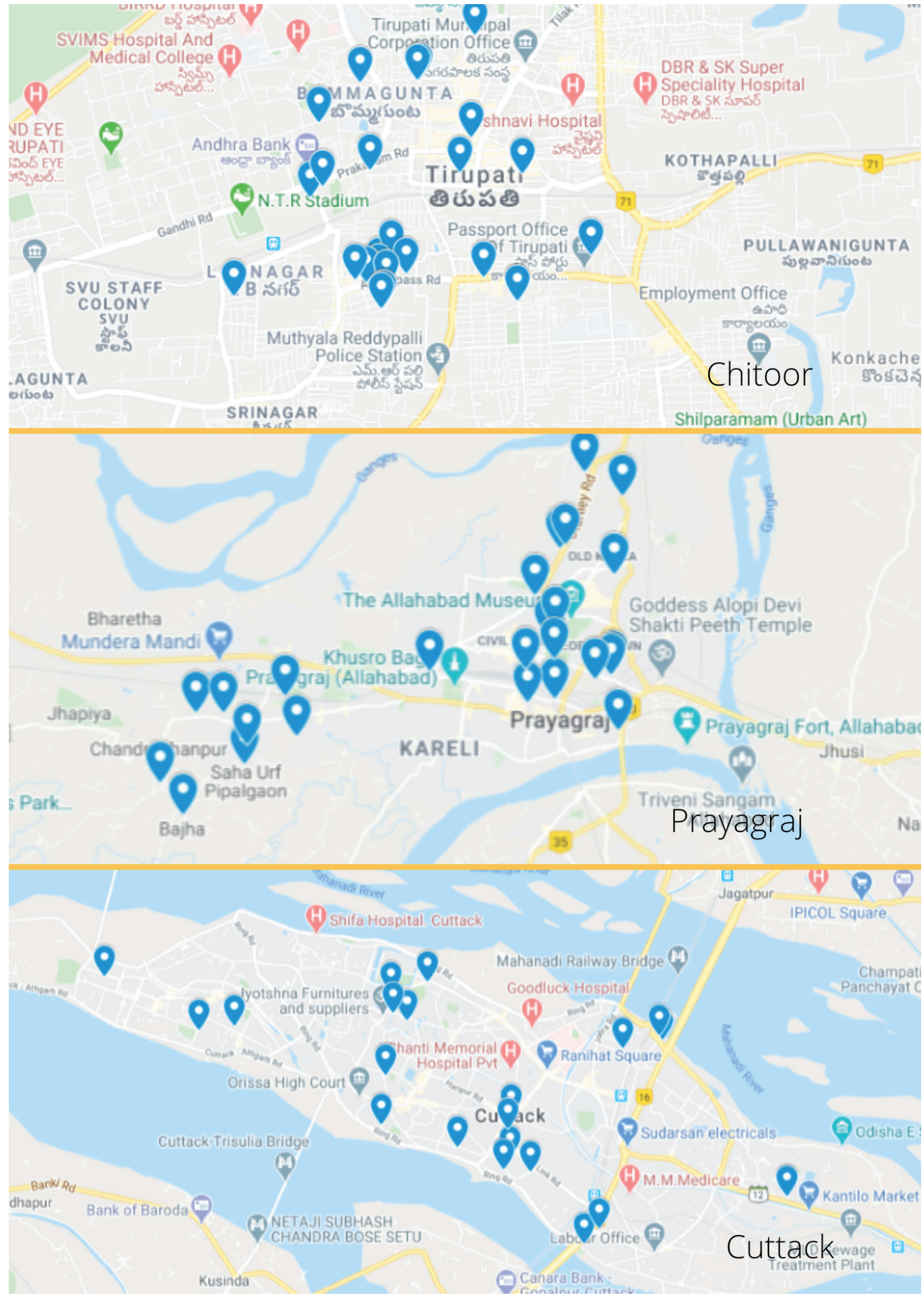


Figure 4. Illustrative photographs of violations of COTPA Section 4

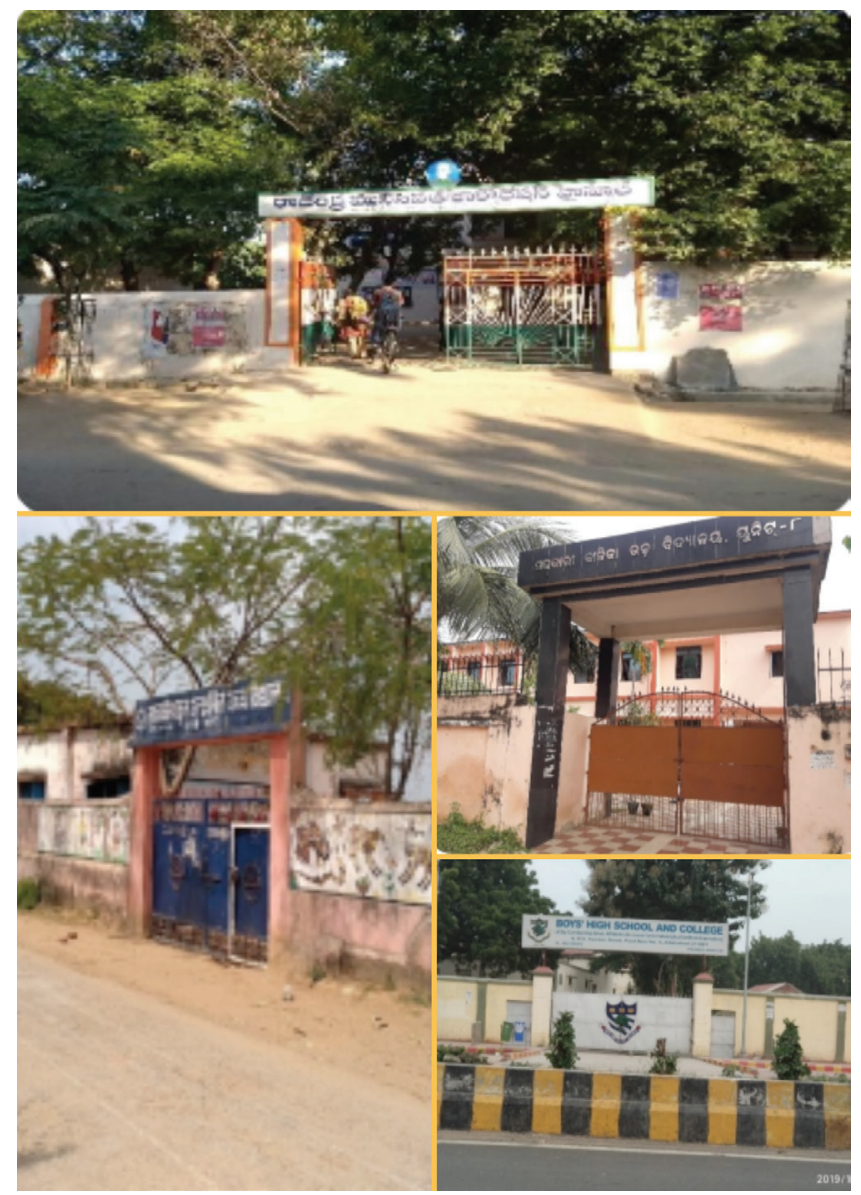

Ranchi districts of Jharkhand an average of $90 \%$ and in Dakshina Kanada and Udupi districts of Karnataka an average of $44 \%$ educational institutions violated Section 4.

\section{Violation of Section $6 b$ of COTPA}

In Anantapur and Chittoor districts of Andhra Pradesh, an average of $80 \%$, in Prayagraj district of Uttar Pradesh an average of 96\%, in Khordha, Cuttack and Puri districts of Odisha an average of $90 \%$, in Gumla, Khunti, Lohardaga and Ranchi districts of Jharkhand an average of $74 \%$ and in Dakshina Kanada and Udupi districts of Karnataka an average of $4 \%$ educational institutions (Figure 5) violated Section $6 b$.

\section{DISCUSSION}

The COTPA was poorly enforced in the 307 schools and colleges selected across 12 districts in 5 states in
Figure 5. Illustrative photographs of violations of COTPA Section $6 b$

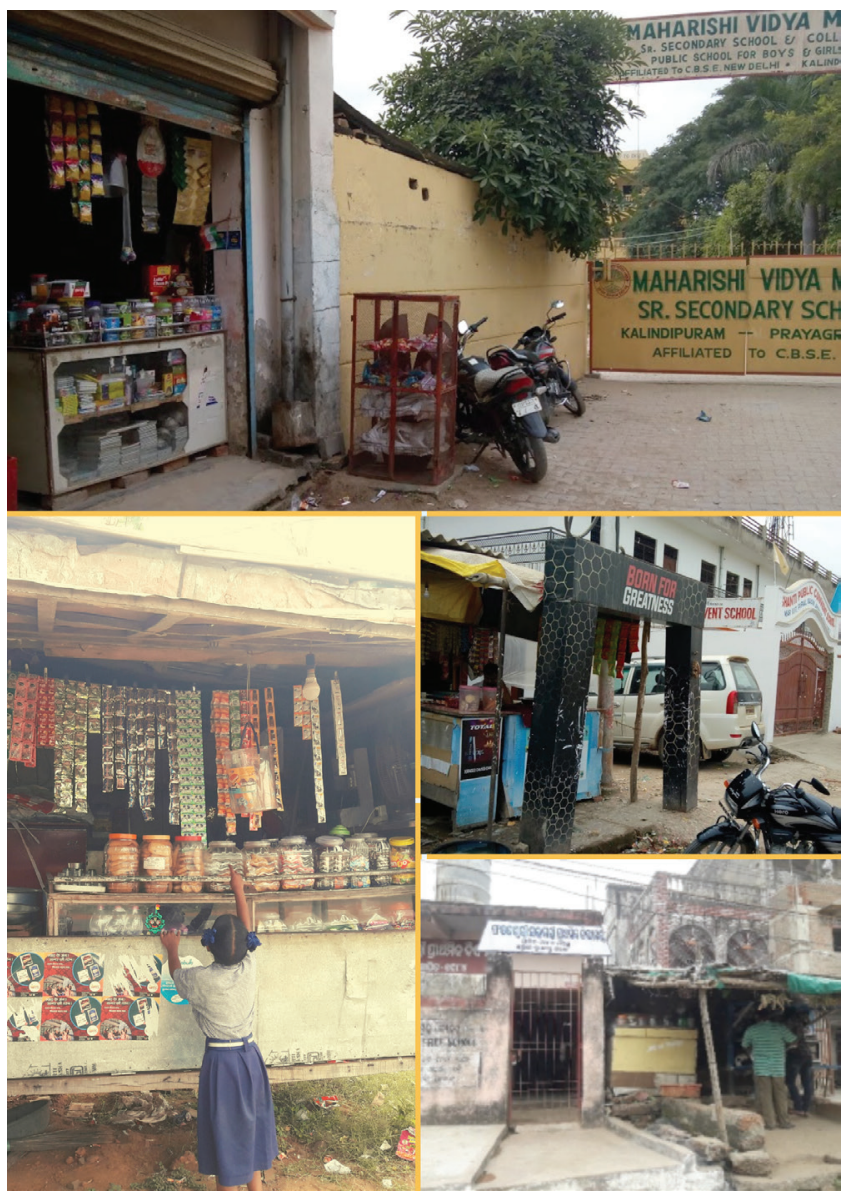

India. Even in those educational institutions where the signage boards were displayed, many were in poor condition. While on average $44 \%$ of the educational institutions observed in Karnataka violated Section 4 of COTPA, violations of Section 4 were observed in more than $90 \%$ of the observed educational institutions in Andhra Pradesh, Uttar Pradesh, Jharkhand, and Odisha. Since the study was conducted as part of a strategy to sensitize higher officers on COTPA law, a modest sample size was required and, hence, a defined area within the city was chosen.

The observed educational institutions in Dakshina Kanada and Udupi districts of Karnataka reported on average $4 \%$ violations, whereas all the other districts reported more than $74 \%$ violations of Section $6 \mathrm{~b}$ of COTPA. A similar study conducted in Bangalore city among 200 educational institutions and public places showed $67 \%$ violated Section 4 and $47 \%$ violated Section $6 b^{11}$. A study conducted by Hriday 
Organisation in Delhi and Tamil Nadu also reported similar results. Overall, $89 \%$ of the public places did not display the "No Smoking Area - Smoking here is An Offence' signage at any entrance ${ }^{12}$.

Students, teachers, law enforcers and the community must be made aware of the COTPA laws, and efforts must be made to ensure its compliance. There are several persons authorized to enforce Sections 4 and $6 \mathrm{~b}$ of COPTA ${ }^{9}$. It is also the role of the person in-charge of affairs at the educational institution to ensure compliance ${ }^{10}$.

The police officials and school/college management are best positioned to ensure strict compliance of COTPA. While Section 4 can be enforced by the active participation of the school authorities, enforcement of Section $6 \mathrm{~b}$ by the school authorities would require the help of police officers, as it requires dealing with shopkeepers selling tobacco products. Training of education and police officials on COTPA laws for educational institutions must be conducted at the district and block level with the help of the District Tobacco Control Cell. Violations of sale of tobacco products around educational institutions must be reported to the nearest police station or the National Quitline (1800-11-2356) $)^{9}$.

The objective of these guidelines was to provide fresh momentum to the implementation of tobacco control initiatives among adolescents and young adults. This will play a pivotal role in ensuring COTPA implementation in educational institutions, which will stimulate positive changes in and around them, potentially leading to higher quit rates and lesser rates of initiation of tobacco use among the students ${ }^{9}$. It is also important to sensitize the District Education Officer and Block Education Officers on these guidelines, which will help in better monitoring. This study helps to understand the level of implementation of COTPA Sections 4 and $6 \mathrm{~b}$ across five states in India. The findings of the study were shared with the respective State and District Education Officers and Superintendent of Police of the respective districts, which led to a series of trainings of the police officials and blockeducation officers. The trainings for police were conducted at district level and at the police stations. Simultaneously, in order to improve compliance, the Superintendent of Police incorporated the status of implementation of COTPA as part of district monthly crime review meetings. This strategy should prove to be effective in motivating action on COTPA among the primary enforcement agencies and regularize reporting of violations of the Act.

\section{Limitations}

This study had limitations. The challenges in the implementation of COTPA may be better understood by interviewing school authorities and police officers. The study focused on only two sections of the COTPA law (Sections 4 and 6b). Section 5 - prohibiting direct and indirect advertisements of tobacco products, and Section 7 - mandatory pictorial warnings, could have given a more comprehensive analysis of tobacco control law implementation across different regions in India.

\section{CONCLUSIONS}

This cross-sectional study showed that COTPA 2003 (Sections 4 and $6 \mathrm{~b}$ ) is poorly implemented in many states in India. A coordinated effort from all stakeholders, especially from the police, educational institutions, and the community, is required to improve this situation. There is a need for creating greater public awareness about the harmful effects of tobacco so that there is more voluntary compliance with the regulations. Complying to the guidelines on Tobacco-Free Educational Institutions can provide a holistic approach to tobacco control and improve the implementation of COTPA in and around educational institutions. The results of this study will help in advocating for better implementation of the tobacco laws and guidelines in the respective states involved in this study and in the country overall.

\section{REFERENCES}

1. World Health Organization. Tobacco: Key facts. https:// www.who.int/news-room/fact-sheets/detail/tobacco. Accessed June 16, 2020.

2. World Health Organization. Cancer: Cancer Prevention. https://www.who.int/cancer/prevention/en/. Accessed June 16, 2020.

3. World Health Organization. Global Adult Tobacco Survey Fact Sheet: India 2016-17. https://www.who.int/tobacco/ surveillance/survey/gats/GATS_India_2016-17_ FactSheet.pdf. Accessed June 16, 2020.

4. Kaur J, Jain DC. Tobacco Control Policies in India: Implementation and Challenges. Indian J Public Health. 2011;55(3):220-227. doi:10.4103/0019-557x.89941 
5. Tobacco Control Laws. Campaign for Tobacco-Free Kids: Legislation By Country, India. https://www. tobaccocontrollaws.org/legislation/country/india/ summary. Published September 17, 2019. Accessed June $16,2020$.

6. Government of India. The Cigarettes and Other Tobacco Products (Prohibition of Advertisement and regulation of Trade and Commerce, Production, Supply and Distribution) Act, 2003. http://legislative.gov.in/sites/ default/files/A2003-34.pdf. Published May 18, 2003. Accessed June 16, 2020.

7. World Health Organization. Global Youth Tobacco Survey (GYTS) Fact Sheet: India (Ages 13-15). World Health Organization. https://www.who.int/fctc/reporting/ Annexoneindia.pdf. Accessed June 16, 2020.

8. Breslau N, Fenn N, Peterson EL. Early smoking initiation and nicotine dependence in a cohort of young adults. Drug Alcohol Depend. 1993;33(2):129-137. doi:10.1016/0376-8716(93)90054-t

9. Ministry of Health and Family Welfare, Government of India. Guidelines for Law Enforcers for effective implementation of Tobacco Control Laws 2013. https:// rctcpgi.org/wp-content/uploads/2018/07/NTCP-LawEnforcers-Manual-2013-1.pdf. Published 2012. Accessed June 16, 2020.

10. Ministry of Health and Family Welfare, Government of India. Guidelines for Tobacco Free Educational Institution (Revised). https://ntcp.nhp.gov.in/assets/document/ TEFI-Guidelines.pdf. Published 2019. Accessed June 16, 2020.

11. Khargekar NC, Debnath A, Khargekar NR, Shetty $\mathrm{P}$, Khargekar V. Compliance of cigarettes and other tobacco products act among tobacco vendors, educational institutions, and public places in Bengaluru City. Indian Journal of Medical and Paediatric Oncology. 2018;39(4):463-466. doi:10.4103/ijmpo.ijmpo_136_17

12. HRIDAY. Implementation of the Framework Convention on Tobacco Control (FCTC) in India: A Shadow Report - 2010. https://www.fctc.org/wp-content/ uploads/2018/05/FCTC-implementation-India-2010. pdf. Accessed June 16, 2020.
ACKNOWLEDGEMENTS

We thank the Programme Coordinators from Tata Trusts, Niraj Kaushik, Shrikanth Gouspure, Ramavath Bhashya, Ambuj Kumar Pandey and Ashish Supase for collecting the data and reporting from their respective districts and states.

\section{CONFLICTS OF INTEREST}

The authors have each completed and submitted an ICMJE form for disclosure of potential conflicts of interest. The authors declare that they have no competing interests, financial or otherwise, related to the current work. A. Sarin and S. Seth report grants from Tata Trusts, during the conduct of the study.

FUNDING

There was no source of funding for this research.

PROVENANCE AND PEER REVIEW

Not commissioned; externally peer reviewed. 